\title{
Remediation and development of a former landfill and rail yard in Virginia USA
}

\author{
R. P. Huguenard ${ }^{1}$, J. M. LaVelle ${ }^{2}$ \& R. L. Olsen ${ }^{3}$ \\ ${ }^{1} C D M$, Atlanta, Georgia USA \\ ${ }^{2}$ CDM, Tucson, Arizona USA \\ ${ }^{3}$ CDM, Denver, Colorado USA
}

\begin{abstract}
Approaches to the redevelopment of contaminated properties vary depending upon many factors including type/extent of contamination, risk, regulatory authorities, cost, the resources/desires of the owners, and the value and demand for the property. This paper presents a case study of the Carlyle Site, a 75-acre Brownfields site in Alexandria, Virginia that has been transformed from a property formerly occupied by landfills, a scrap yard, a rail yard, and other commercial and industrial operations to a desirable, mixed use commercial/residential/retail district that includes mid-rise office buildings, upscale high-density residential buildings, and retail space. Environmental management planning played a key role in decision making at each step of the redevelopment process for each property, starting with the conceptual planning and purchase and sale negotiations, and proceeding through construction and environmental closure. The integration of proactive and innovative environmental management approaches with development planning and execution was successfully used to control overall environmental costs, maximize property value, and provide the owner with a larger return on his investment.

Examples of the role of environmental management at each step in the redevelopment process include:

- Considering environmental factors during development master planning to minimize overall development cost.

- Considering environmental conditions in sequencing of property marketing and development.

- Managing perceived environmental risk to maximize property value and minimize costs.

- Using effective risk based remediation goal setting.

- Benefits of regulatory Brownfields or Voluntary Remediation Programs.

- Using in situ characterization and soil management plans to obtain regulatory acceptance, minimize handling, and reduce costs and cleanup times.
\end{abstract}

Keywords: contaminated sites, cleanup, remediation, redevelopment. 


\section{Introduction}

The investigation, remediation, and development of contaminated sites in the USA occurs in many different ways using various approaches depending upon the type/extent of contamination, the environmental and human health risk, the regulatory authorities, the remediation cost, the site owners/developers, and the property value and demand [1-3]. The Carlyle Site is a 75-acre commercial and residential development located in Alexandria, Virginia near the "Old Town" section of the City. The Carlyle Site is an attractive site for development because of its unique proximity to downtown Washington D.C., Ronald Reagan National Airport, major transportation thoroughfares (commuter rail lines and highways), and the amenities available in the City of Alexandria. The site has been divided into 16 parcels for redevelopment (Blocks A to P, see Figure 1). The Carlyle Site was not a single project or redevelopment effort. Instead the site was developed parcel by parcel by different developers. The common link between the parcels was Norfolk Southern Corporation (NSC), which was the property seller and the overall site developer (i.e., responsible for establishing the site development master plan, zoning approvals, installation of roads, installation of infrastructure, etc.). Each property purchase and sale agreement included negotiated language defining the distribution of short-term and long-term environmental liability and responsibility. Remediation on each parcel was completed concurrent with development and involved a coordinated effort between NSC and the parcel developer. The focus of this paper is the development of a 15-acre parcel for the U.S. Patent and Trademark Office (USPTO) campus. The development was performed in parcels $\mathrm{J}, \mathrm{K}, \mathrm{M}, \mathrm{N}, \mathrm{F}$ $(1 / 2)$, and $\mathrm{G}(1 / 2)$ (see Figure 1).

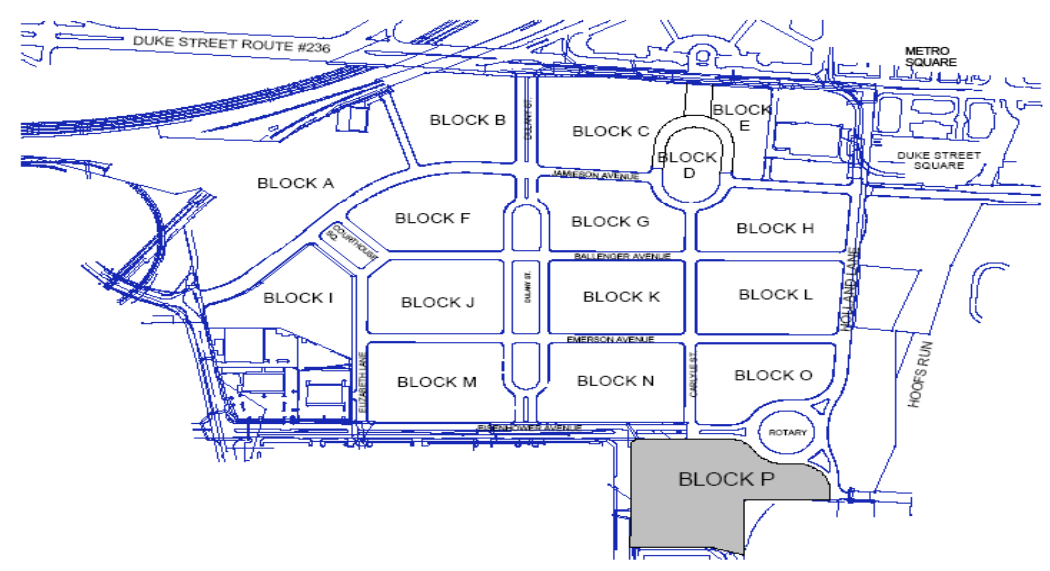

Figure 1: $\quad$ Site location. 
The development was made possible through the cooperative efforts primarily of the property owner and project developer (Carlyle Development Corporation, a subsidiary of NSC), the parcel developer (LCOR Alexandria, LLC), the environmental consultant for the land transfer, environmental management planning, and remediation (CDM), the project architect (Skidmore, Owings \& Merrill LLP), the general contractor (Turner Construction Company), and the remediation contractor (Weston Solutions Inc.).

For this site, the following items are discussed:

- Site background including types and sources of contamination.

- Remediation approaches.

- Soil Management Planning.

- Conclusions.

\section{Carlyle Site description}

\subsection{Site background}

The Carlyle Site is situated in south central Alexandria, Virginia in an area formerly known as West End. Native Americans inhabited the area for thousands of years before the area was explored by Europeans in the early 17th century. Royal grants brought the area into private ownership in 1669, and plantation settlements began in the early 18th century. The eventual intersection of three early colonial roads encouraged trade in the area and the founding of the Village of Cameron, on the site's western edge.

Cameron, later to become known as West End, established itself as a thriving community and expanded to include what is now the new USPTO site. Alexandria annexed the West End in 1915 and the city's growth as a seaport enhanced the importance of the roads that fed the West End. The Orange and Alexandria Railroad established rights-of-way and constructed tracks immediately north of the site in 1851 to provide service to the Potomac River, a couple of miles east of the site. The railroad further stimulated the area's growth.

During the Civil War, it became of strategic value to the Union Army, which constructed a major hospital and the Slough Barracks. Following the war, industrialization came to West End with the establishment of a glass container manufacturing plant, construction of Cameron Yards by Southern Railway, and operation of railroad repair and servicing facilities. The rail yard attracted other industries, and in 1953, landfilling began in the Cameron Run floodplain south of the rail yard (including the southern portion of the USPTO site). Landfilling was terminated in 1978, and the landfill was closed and covered. A scrap yard also was established on a parcel adjacent to the rail yard in mid-1953. The scrap yard consisted of about 10 acres of land that was leased from the railroad from 1954 until the early 1990s.

The railroad yard, which was built after the Civil War, consisted of a switching yard and was expanded in 1901 to include a steam locomotive roundhouse and again in 1944 to include a diesel locomotive repair shop. The 
roundhouse ceased to be used for railroad purposes in the early 1970s and was leased to a lumber company for warehouse purposes until 1997, when it was demolished as part of the Carlyle infrastructure development on that part of the site. After the merger of Southern Railway and Norfolk and Western in 1982 and subsequent consolidation of certain facilities, the rail yard and diesel shop were abandoned and eventually removed in the early 1990s in connection with the initial Carlyle infrastructure development.

Figure 2 provides an aerial view of the site prior to remediation and development.

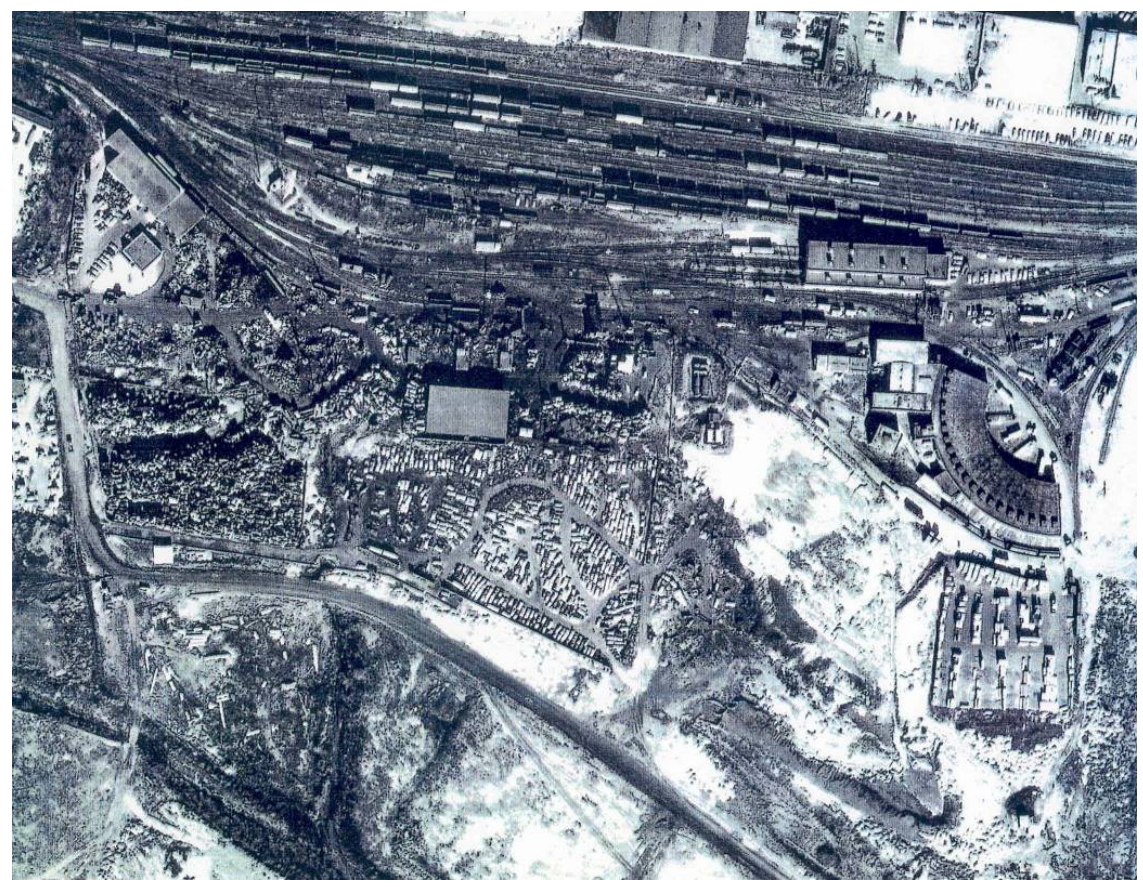

Figure 2: $\quad$ Aerial view prior to remediation and development.

\subsection{Site environmental setting}

The Carlyle Site is relatively flat with elevations ranging between 10 feet to 50 feet above sea level. Elevations are greatest along the northern boundary of the site and gradually slope toward the southwest corner of the site. Regionally, the highest elevation is Shooters Hill, at about 150 feet above mean sea level (msl). The principal surface water bodies in the vicinity of the property are Old Cameron Run (about 500 feet to the south), Hooffs Run (about 200 feet east), Cameron Run (about one-third mile south), and the Potomac River (about two miles East). The elevation of these streams approaches sea level. The original land surface elevation ranged from 22 feet above msl in the north to five feet above msl in the south. 


\subsection{Site geology}

The Carlyle Site is located near the western edge of the Atlantic Coastal Plain physiographic province, which consists of unconsolidated sediments (e.g., clays, silts, sands, and gravels) formed by erosion of the inland mountains. Geologic maps indicate that most of the site is covered with artificial fill underlain by terrace and alluvial deposits and clays, silts, and sands of the Cretaceous Potomac Group [4]. This formation consists of an interbedded series of silt, sand, clay, and gravel. At the fall line, these sediments are very thin, while near the Potomac River, they are up to 600 feet thick.

At the City of Alexandria's southern border with Fairfax County, the lower sands of the Potomac Formation act as a deep aquifer. However, the surficial soils, where the Potomac Formation occurs on the site, are predominantly composed of clays and silts. East of the Potomac sediments lies a loose, heterogeneous material composed of fine grained soil, decomposed rock, and coarse angular rock fragments. At the surface, the fragments have been removed by weathering or erosion. Collectively, these deposits are known as colluvium, and the majority of the site lies over this collection.

Boring $\operatorname{logs}$ at the Site indicate that the northern portion of the site is underlain by two to three feet of man-placed fill overlaying clays and silts occasionally interbedded with thin layers of silty or clayey sands. Borings on the southern part of the Site indicate that up to 35 feet of fill soil and landfill material have been placed over natural soils. The natural soils include 5 to 25 feet of a mixture of organic alluvium and Pleistocene terrace deposits underlain by deposits of clays and gravelly, silty, or clayey sands, which are presumed to be deposits of the Potomac Group.

\subsection{Groundwater}

The geologic materials present at the site are generally low permeability clays and silts with thin lenses of slightly higher permeability material. However, the higher permeability materials do not appear to be consistently continuous across the site. Because of this low permeability base, groundwater movement occurs mostly laterally toward Old Cameron Run and Hooffs Run to the south and the east, respectively. No drinking water wells are known to exist in either the surficial aquifer or the deeper aquifer at the site or downgradient of the site.

While the original groundwater levels and flow directions were ultimately controlled by water levels in Old Cameron Run and Hooffs Run, certain engineered controls on the parcels significantly alter the groundwater regime. For example, the properties in Block $\mathrm{O}$ and Block $\mathrm{L}$ contain buildings with basements near elevation 0 . To protect the buildings, permanent underdrain systems were installed below the bottom slabs. The USPTO Site also includes engineered groundwater controls. Each of the buildings on the USPTO site is equipped with below slab underdrain systems to protect the buildings. In addition, a groundwater barrier (an interlinking system of clay subsurface barriers and synthetic liner barriers) was installed in an east-west direction across 
the southern part of the USPTO property to minimize the need for groundwater management (pumping and treatment) in association with the buildings located above the former landfill.

\section{Carlyle Site remediation}

\subsection{Contamination}

The primary contaminants at the site included lead, arsenic, polychlorinated biphenyls (PCBs), and petroleum hydrocarbons (TPH). Lead, arsenic, PCB, and $\mathrm{TPH}$ concentrations in soil ranged from non-detectable to about $24,700 \mathrm{mg} / \mathrm{kg}$, $90 \mathrm{mg} / \mathrm{kg}, 48 \mathrm{mg} / \mathrm{kg}$, and 20,000 mg/kg, respectively. In addition, about half of the USPTO site had been used previously as a municipal landfill site and was underlain with buried landfill material, incinerator ash, tires, scrap yard remnants, and an occasional drum, tank, and unexploded ordnance. The contaminated soil and landfill material extended over the entire 15-acre site.

\subsection{Regulatory history}

NSC has a long history of regulatory and community interactions as part of the development plans for the Carlyle Site. In 1989, Norfolk Southern Railway Company began discussions with the Virginia Water Control Board and the Virginia Department of Waste Management (VDMW), both now part of the Virginia Department of Environmental Quality (VDEQ), and the City of Alexandria Health Department on the voluntary cleanup at the Carlyle Site. Subsequently, NSC (through subsidiary corporations) has entered several properties at the Carlyle Site into the voluntary remediation program. Remedial actions and development has been completed and certifications of completion have been obtained on properties entered into the program. Thus, VDEQ and the City have been closely involved in the decision making related to assessment and cleanup activities at the property since 1989. As a result of these interactions, remedial activities have been successfully completed on the majority of the site.

\subsection{Cleanup goals}

The USPTO property was enrolled in the VDEQ Voluntary Remediation Program (VRP). Site characterization work was performed according to work plans. Based on the characterization, a risk assessment was performed to establish risk-based cleanup goals [5,6]. Results of the in situ sampling and coordination with the VDEQ Solid Waste Division resulted in preapproval of soil and waste disposal characteristics and disposal requirements (see Section 4). Additional negotiations resulted in limiting the removal of contaminated soil and buried waste to the depth of the building foundations. In addition, agreements were reached with landfills on special low cost disposal options (e.g., as daily cover) for certain categories of material. Negotiations with the local POTW established temporary industrial discharge permits to allow discharge of partially treated impacted groundwater to the sanitary sewer system. Plans and 
specifications for the excavation and disposal of soil and waste and the management and treatment of groundwater were prepared concurrent with development.

\subsection{Remediation}

Remediation alternatives were evaluated based on effectiveness in meeting cleanup goals, implementability, costs, and time to achieve the cleanup goal. In addition, remediation was performed to facilitate phased property development in accordance with economically driven build-out plans and demand for the property.

For the USPTO Site, a site investigation was performed to characterize soil, landfill material, and groundwater. This occurred concurrent with negotiations between the owner, developer, and purchaser. A risk assessment was then performed and risk-based remediation goals were developed, resulting in the necessary removal of soil and landfill material for foundation excavation while leaving other soil and landfill material in place. Residual risks were managed using a combination of deed restrictions and engineering controls. Deed restrictions included prohibitions on potable water well installation and constraints on water use and residential use restrictions. Engineering controls included installation of vapor barriers and subslab gas ventilation systems under each building, and placement of two feet of clean soil over all existing soil that was not covered by pavement or buildings.

To meet schedule constraints, soil and landfill material was characterized for disposal in situ, and a soil management plan/excavation design was developed to expedite material removal (see Section 4). Under this approach, the remedial contractor was able to move soil and waste directly from the ground to trucks with a predetermined disposal destination. As a result, as many as 600 tandem truckloads of soil and waste were removed from the site each day, and a total of approximately 450,000 total cubic yards of soil and waste were removed from the site during a six-month period.

The new USPTO development included construction of five mid-rise office buildings $(2,400,000$ square feet of office space) and two large parking garages. Foundation excavation work progressed from structure to structure, followed immediately by piling installation, foundation forming, and then concrete placement. The integrated planning of the environmental and construction components was robust so that schedules were maintained even with the additional challenges of weather and archaeological investigations.

The remediation and redevelopment process took approximately nine years, starting with the development of a proposal for construction of the USPTO offices at the Carlyle Site in 1996 and culminating with the issuance of a certificate of completion by the VDEQ VRP in 2005. The major milestones in this process were:

- 1988 - Plans to consolidate the USPTO offices were initiated

- 1990 - Zoning approval issued by the city of Alexandria

- 1995 - Congressional approval was granted to lease two-million square feet of office space in Northern Virginia for a period of 20 years 
- 1996 - The General Services Administration (GSA) solicitation

- 2000 - The GSA and the USPTO selected the LCOR proposal for development of the new USPTO offices at the Carlyle site

- 2000 - Site environmental investigation and environmental planning were initiated

- 2001 - Construction began

- 2005 - Building construction was completed

- 2005 - A Certificate of Completion was issued by the VDEQ, VRP

Project costs by category are:

Land purchase

$\$ 92,000,000$

Environmental management planning, permitting, design, and remediation oversight

$$
\$ 2,000,000
$$

Environmental remediation

$\$ 24,000,000$

USPTO campus design

$\$ 31,000,000$

Campus construction costs

$\$ 518,000,000$

Finance

$\$ 191,000,000$

Reserves

$\$ 16,000,000$

Miscellaneous

$\$ 38,000,000$

Total

$\$ 912,000,000$

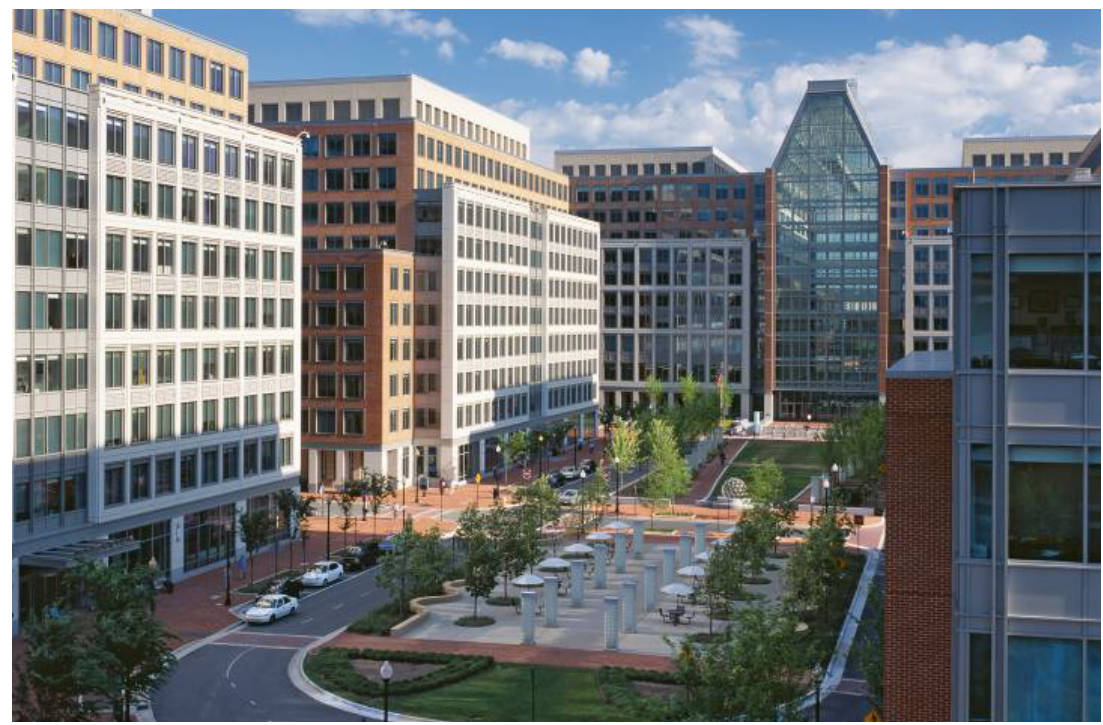

Figure 3: Dulany Garden and surrounding USPTO campus.

Innovative thinking and cooperation between the seller (a subsidiary of NSC) and the buyer (LCOR Alexandria, LLC) was the key to arriving at an acceptable agreement for transfer and development of the contaminated property that would become the site of the new USPTO campus. Cost and environmental liability concerns were managed through a combination of a negotiated cost sharing arrangement and a cooperative environmental management approach. 
The resulting USPTO project is a model for positive economic development and smart growth. While directly adding 8,000 jobs in the City of Alexandria, its proximity to two metro subway stations, Amtrak, the Virginia Railway Express, and numerous commuter bus lines resulted in manageable impacts to the local traffic.

The USPTO project also included the development of park area. Dulany Gardens, one of the two largest open spaces planned for Carlyle, features two distinct plazas - one with primarily hardscape finishes designed for outdoor seating and dining and the other with extensive lawn, plantings, and a distinctive fountain (Figure 3). The Gardens is designed to terminate at the monumental atrium of the Madison Building.

\section{Soil management planning}

\subsection{Objectives and scope of the soil management planning}

The overall goal of soil management plans was to obtain predevelopment buy-in from the VDEQ on soil and landfill material management and disposal to allow remediation to occur concurrent with development while minimizing potential delays for environmental decisions [7]. The soil management plans were not a regulatory requirement, but were a cooperative approach developed by CDM and the VDEQ to solve problems each party faced. Potential large delays would be encountered if disposal decisions and approvals were made with each batch of material removed from the site and the VDEQ faced management of a tremendous number of special waste approval requests. The following specific objectives were accomplished by soil and waste management plans:

- Present analytical data and field observations.

- Horizontally and vertically delineate soils and waste with regards to handling and disposal requirements.

- Delineate the approximate vertical extent of the landfill when present.

- Develop contingency plans to identify and address potential problems that may be encountered during development excavation.

\subsection{Potential environment issues}

The following environmental issues were typically encountered during development:

- Landfilled Material - Landfilled material was encountered during excavation on the southern portions portion of the site and required proper handling and disposal.

- Landfill Gases - Landfill gases were a common problem that had to be addressed.

- Groundwater - Much of the excavation required digging into the groundwater table. Some groundwater required treatment and special disposal, while other required only standard silt/sediment control. 
- Resource Conservation and Recovery Act (RCRA) Hazardous Waste - A small portion of the waste was hazardous due to lead concentrations.

- Soils Impacted by Metals - Lead and arsenic were common contaminants across the site and required special handling and/or disposal if they were removed from the site or reused onsite.

- Soils Impacted by TPH and/or PCBs - Some soils removed from the site or reused onsite also required special handling and/or disposal due to slightly elevated levels of TPH and/or PCBs. A small amount of the waste had PCBs over $50 \mathrm{mg} / \mathrm{kg}$ and required disposal to TSCA waste facilities.

\subsection{Soil and landfill material characterization}

The purpose of the site investigation was to characterize soils and landfill material that will be excavated during development for disposal or reuse [5]. The resulting soil and landfill material chemical and physical characterization results allowed predevelopment planning of environmental management during construction and ultimately minimized delays in development due to environmental issues. The sample frequency established for the site investigation provided sufficient data to satisfy the soil and waste characterization requirements of the landfills that will receive the soil and waste. Specific objectives of the site investigations included:

- In situ characterization of the soil and landfill material that will be excavated for development. Characterization was sufficient to 1) allow horizontal and vertical delineation of soils and waste with regards to disposal requirements, and 2) allow pre excavation acceptance of the soils and waste by the selected landfills.

- Examine soil and landfill materials in soil boring cores to visually characterize the landfill contents by horizon.

The soils and landfill material were characterized both visually through boring logs and chemically through laboratory analysis. In known landfill areas, borings were performed on a 50-ft grid spacing. On nonlandfill areas, the grid spacing was $100 \mathrm{ft}$. The boring depths were selected to coincide with the proposed excavation depths. Cores from soil borings were visually characterized and then sampled at three-foot intervals and sent to laboratories for analysis. The specific chemical analyses performed from borings in landfill areas are described below in Table 1.

In nonlandfill areas, samples were analyzed for total arsenic, total lead, TPH gasoline range organics, and TPH diesel range organics. If TPH was detected, the samples were also analyzed for BTEX, TOX and PCBs. If total metals exceeded twenty times the TCLP limits, the samples were analyzed for TCLP metals (only the specific metals). Visual observations of the physical characteristics of the soils and landfill materials were made and recorded during boring installation. Each sample was classified according to geologic characteristics, color, texture, and landfill waste content. Soil and landfill material chemical characteristics were obtained through testing at an analytical 
laboratory. The chemical and physical data for each boring location and depth were then evaluated to characterize the materials in terms of reuse or disposal criteria. Cross-sections presenting the chemical data and the disposal characterization were constructed. A cross-section was presented for each of the analytical parameters that had an impact on determining the disposal criteria (TPH, Arsenic, Lead, BTEX, PCBs, and TOX).

Table 1: $\quad$ Analysis of material samples.

\begin{tabular}{|l|l|}
\hline \multicolumn{1}{|c|}{ Parameter } & Frequency \\
\cline { 1 - 1 } Total petroleum hydrocarbons (TPH) gasoline range organics & All samples \\
\cline { 1 - 1 } Total petroleum hydrocarbons (TPH) diesel range organics & \\
\cline { 1 - 1 } TCLP arsenic and lead (for classification as hazardous waste) & \\
\cline { 1 - 2 } $\begin{array}{l}\text { Full TCLP (i.e., metals, volatiles, semivolatiles, pesticides, } \\
\text { herbicides) (for classification as hazardous waste) }\end{array}$ & $\begin{array}{c}\text { Every eighth } \\
\text { sample }\end{array}$ \\
\cline { 1 - 1 } PCBs in solids & $\begin{array}{c}\text { Samples in } \\
\text { which TPH } \\
\text { is detected }\end{array}$ \\
\hline
\end{tabular}

The reuse and disposal criteria identified in the cross-sections were also presented in plan view by horizon to better facilitate excavation planning. The plan views were presented in horizons of at least two feet starting at the land surface and ending at the deepest excavation depth. Typical disposal and reuse categories used for classification of the samples are presented and explained in Table 2 .

Some soils (see Table 2) were reused onsite. However, reuse of soils was only allowed in locations that were covered by buildings or two feet of clean fill as part of the site development. In addition, reuse of soils was not allowed in utility corridors.

Temporary stockpiling or staging of soils to be reused onsite was necessary. Where creation of soil stockpiles was necessary, the stockpiles were plastic lined and had surface water run on and run off controls and sedimentation controls. The stockpiles were covered with plastic at the end of each day.

Materials coded as RCRA hazardous waste or PCB wastes were either directly loaded into trucks for hauling to an appropriate disposal site or loaded into covered hazardous waste roll-off containers for staging onsite. All other excavated soils or materials were directly loaded into trucks for offsite disposal.

One of the primary goals of soil and landfill material management plans was to maximize the efficiency of the development excavation process by minimizing delays required for management of environmental issues. Contingency plans were a critical tool for meeting this goal. The plans were developed to establish general protocols and procedures for dealing with issues and problems that were not necessarily identified by the site investigation, but have a reasonable potential for occurring. Contingency plans were included to establish general protocol and procedures to use when the following issues and problems were encountered. 
Table 2: $\quad$ Material classification.

\begin{tabular}{|l|l|}
\hline \multicolumn{1}{|c|}{ Material Description } & \multicolumn{1}{|c|}{ Disposal/Reuse Requirement } \\
\hline $\begin{array}{l}\text { Soil with TPH }<500 \mathrm{mg} / \mathrm{kg} \text { and } \\
\text { remaining constituent concentrations at } \\
\text { or below prevailing site concentrations }\end{array}$ & $\begin{array}{l}\text { Restricted onsite reuse or disposal at an } \\
\text { appropriate, permitted lined landfill }\end{array}$ \\
\hline $\begin{array}{l}\text { Soil with TPH between } 500 \mathrm{mg} / \mathrm{kg} \text { and } \\
\text { below } 3,000 \mathrm{mg} / \mathrm{kg}\end{array}$ & $\begin{array}{l}\text { Disposal at an appropriate, permitted } \\
\text { lined landfill }\end{array}$ \\
\hline Soil with TPH above 3,000 $\mathrm{mg} / \mathrm{kg}$ & $\begin{array}{l}\text { Treatment and disposal at an } \\
\text { appropriate, permitted TPH incineration } \\
\text { facility or other appropriate offsite } \\
\text { treatment and disposal facility }\end{array}$ \\
\hline $\begin{array}{l}\text { Landfill material with TPH below } 500 \\
\text { mg/kg }\end{array}$ & $\begin{array}{l}\text { Disposal at an appropriate, permitted } \\
\text { lined landfill }\end{array}$ \\
\hline $\begin{array}{l}\text { Landfill material with TPH between } \\
500 \mathrm{mg} / \mathrm{kg} \text { and 3,000 } \mathrm{mg} / \mathrm{kg}\end{array}$ & $\begin{array}{l}\text { Disposal at an appropriate, permitted } \\
\text { lined landfill }\end{array}$ \\
\hline $\begin{array}{l}\text { Landfill material with TPH greater than } \\
3,000 \mathrm{mg} / \mathrm{kg}\end{array}$ & $\begin{array}{l}\text { Treatment and disposal at an } \\
\text { appropriate, permitted TPH incineration } \\
\text { facility or other appropriate offsite } \\
\text { treatment and disposal facility }\end{array}$ \\
\hline $\begin{array}{l}\text { RCRA hazardous waste, soil, or } \\
\text { landfill material }\end{array}$ & $\begin{array}{l}\text { Treatment and disposal at an } \\
\text { appropriate, permitted RCRA hazardous } \\
\text { waste facility }\end{array}$ \\
\hline $\begin{array}{l}\text { TSCA PCB contaminated soil or } \\
\text { landfill material (PCB above } 50 \mathrm{mg} / \mathrm{kg}\end{array}$ & $\begin{array}{l}\text { Treatment and disposal at an } \\
\text { appropriate, permitted TSCA PCB waste } \\
\text { facility }\end{array}$ \\
\hline
\end{tabular}

- Buried Ordnance or Other Unidentified Objects - A limited amount of unexploded ordnance (unarmed) and other unidentified objects were encountered during remediation efforts in the landfilled areas.

- Compressed Gas Cylinders - A limited number of compressed gas cylinders were encountered during remediation efforts in the landfilled areas.

- Underground Piping and Other Utility Lines - Due to the long history of the Carlyle Site, previously unidentified piping and utilities were sometimes encountered during excavation.

- Tanks - In view of the historic use of the property, it was considered prudent to establish a contingency plan for this issue.

- Drums - Some drums were encountered during remediation efforts in the landfilled areas.

- Material Varying from Assigned Classification - Soil or landfill material that was inconsistent with the assigned disposal classification was occasionally encountered.

- Buried Structures - This contingency plan outlines procedures and protocols that should be followed in the event that additional structures were encountered. 
- Rejection of Waste by the Landfill - Because of the extensive waste characterization activities that have been performed prior to waste disposal, no waste from the Carlyle Site should be rejected by a receiving landfill. However, it was considered prudent to establish a plan that addressed this potential issue.

\section{Conclusions}

Approaches to redevelopment of contaminated properties vary depending upon many factors including type/extent of contamination, environmental/human health risk, regulatory authorities, costs, the resources/ desires of the owners/developers, and the value and demand for the property. Overall, the remediation and development on the Carlyle Site demonstrated the importance of integrating environmental management with development planning and execution. Specific examples of this integration and lessons learned include:

- Risk based exposure pathways can be minimized through use of institutional controls (e.g., deed restrictions) and development features (e.g., barriers such as subslab ventilation, clean soil cover and pavement; placement of buildings to avoid groundwater contamination; placement of recreational areas on less contaminated property).

- Up front land use planning should include environmental implications. The development configurations should be flexible if risk assessment provides acceptable solutions. If feasible, acceptable residual risk should be the goal versus fixed remediation goals.

- $\quad$ Property sale prices are influenced more by perceived environmental risk than by actual risk. The perceived risk should be managed by securing regulatory support and up front concurrence on management approaches. The regulators should be continually involved and informed.

\section{References}

[1] Olsen, R.L., Woods, A.B. \& Edgar, M.H., Remediation and Development of a Former Military Manufacturing and Test Site in Florida USA, Third International Conference on Prevention, Assessment, Rehabilitation and Development of Brownfield Sites, WIT Transactions on Ecology and the Environment, Vol. 94, WIT Press, Southampton and Boston, pp 121 -130, 2006.

[2] Olsen, R.L. \& Burgess, M.A., Case Histories and Comparison of Two "Brownfields" Sites in Kansas and Indiana USA, Second International Conference on Brownfield Sites: Assessment, Rehabilitation and Development, WIT Press, Southampton and Boston, pp 191-200, 2004.

[3] Whitman, I.L., Brownfield Redevelopment by the Private Sector: Market Driven Decision-making, Third International Conference on Prevention, Assessment, Rehabilitation and Development of Brownfield Sites, WIT Transactions on Ecology and the Environment, Vol. 94, WIT Press, Southampton and Boston, pp 21 - 27, 2006. 
[4] U.S. Geological Survey (USGS), Geology and Groundwater Resources of Washington, DC, and Vicinity, USGS Water-Supply Paper \#1776. U.S. Government Printing Office, Washington, DC, 97 pp, 1983.

[5] CDM, Site Characterization and Remedial Action Planning Report, Block P, Carlyle Site, Alexandria, Virginia, Sept. 2006, submitted to VDEQ on behalf of Carlyle Development Corporation, 2006.

[6] Virginia Department of Environmental Quality (VDEQ), Voluntary Remediation Program Draft Risk Assessment Guidance, Richmond, VA, 1999.

[7] CDM, Soil and Landfill Material Management for the Development of Block $P$, Carlyle Site, Alexandria, VA, submitted to VDEQ on behalf of Carlyle Development Corporation, 2007. 